\title{
THE CHOICE OF PROJECT GOVERNANCE MODES TO MINIMISE CONTRACTORS' OPPORTUNISTIC BEHAVIOUR
}

\author{
B.P. Arsecularatne ${ }^{1}$ and Y.G. Sandanayake ${ }^{2}$
}

\begin{abstract}
In this era of globalisation and fierce competition among businesses, contractors in the construction industry often tend to engage in opportunistic behaviour to gain more benefits at the expense of owners. The past researchers have defined contractors' opportunistic behaviour (COB) as the behaviour of the contractor that is motivated to pursue self-interests at the expense of the client. The researchers in this field have identified project governance $(P G)$, which considered as management of project management can be used to minimise the COB. Trust and formal control are the major $P G$ modes that are used in the global construction industry. However, there is a dearth of research that identified the suitable PG modes to minimise the effects of $C O B$ in the Sri Lankan construction industry. Hence, this study aims to investigate the PG modes that can be used to minimise the effects of COB. Accordingly, qualitative research approach was adopted to achieve the research aim. A comprehensive literature review followed by case studies was conducted to investigate the synergy between the concepts. Information gathered were subjected to content analysis. This study revealed that formal control and combination of trust and formal control as the most suitable PG modes for Sri Lankan construction industry. The research further identified the factors that affect the COB namely, contractors focus on revenue maximisation, external uncertainties, contractual complexity, and dynamic complexity. The study further highlighted the importance of minimising $\mathrm{COB}$ to help minimise conflicts and reduce the financial losses incur for project stakeholders.
\end{abstract}

Keywords: Construction industry; Contractors' Opportunistic Behaviour (COB); Formal control; Project Governance (PG); Trust.

\section{INTRODUCTION}

Poor performance and low efficiency of construction projects have set the practitioners and researchers to think more about performance and efficiency (Bankvall et al., 2010). Lu et al., (2015) identified that the over the course of the last few years, profit rates in the construction industry have been decreased to become lower than other industries. Love, Irani, and Edwards (2004) identified lack of coordination among participants to construction projects as the root cause of the problems. Zhang and Qian (2017) explained that relationships between the owner and contractor have a major impact on project performance in the construction industry. In construction projects, contractors often engage in opportunistic behaviour to gain more benefits at the expense of clients or other

\footnotetext{
${ }^{1}$ Department of Building Economics, University of Moratuwa, Sri Lanka, buddhikaarsecularatne.ba@gmail.com

${ }^{2}$ Department of Building Economics, University of Moratuwa, Sri Lanka, ysandanayake@uom.lk
} 
stakeholders (Cheung et al., 2014). As stated by Shi et al. (2018), it can be divided into strong and weak forms. It is found that trust and formal control are two regular modes of project governance (PG) that can be utilised to execute governance in projects, which are widely viewed as reasonable techniques that can decrease opportunistic behaviour to a certain level (Meng, 2015).

The two governance methods would lead to different project outcomes, and it may provide different outcomes to different projects due to the unique nature of each and every construction project. Thus, there are numbers of gaps that still not filled related to the project governance and there is a necessity to identify the use of project governance to reduce the effect of contractors' opportunistic behaviour (COB) to maximise the project performance and identify the factors that directly affect to the contractors' opportunistic behaviour. Hence, this paper aims to investigate the project governance modes that can be used to minimise the effects of contractors' opportunistic behaviour. In order to achieve the aim, the paper is organised as follows. First, a literature review, which discuss about opportunistic behaviour and project governance. This is followed by a justification of data collection methods used and the results of the study.

\section{LITERATURE SYNTHESIS}

\subsection{THE OPPORTUNISM AND THE OPPORTUNISTIC BEHAVIOUR}

Opportunism is characterised as a behaviour by a party that seeks after personal interests with deceiving the other party with their expense (Das and Rahman, 2010). Opportunism was frequently connected with negative feelings and incorporates activities such as stealing, cheating, breach of contract, deceitfulness, twisting information, jumbling issues, confusing transactions, bogus threats and promises, cutting corners, cover-ups, disguising attributes and preferences, retaining data, misdirection, and deception, as some examples (Crosno and Dahlstrom, 2008). Opportunism without much of a stretch is envisioned and dispensed with through governance (Verbeke et al., 2019). The interaction between formalisation and unity and also participation's link with role integrity and commonality appears to improve opportunism. In contrast, the interaction between formalisation and role integrity decreases opportunism (Paswan et al., 2017). Opportunistic behaviour (OB) considered as an act or behaviour of partnership motivated by the maximisation of economic self-interest and occasioned the loss of the other partner which is very much similar to the opportunism definitions (Luo, 2006). The vital fact about OB was such behaviour not always exists, but the possibility of OB was always present (Sulong et al., 2018). Furthermore, the authors mentioned that most people act honourably and do the right things, and some do more than what required from them, however, there are always a few who are without conscience and would not perform in the best interest of all parties but rather acting for their interest.

The relationships between client and contractor have a major effect on project performance in the construction industry (Drexler Jr and Larson, 2000). Despite the fact that temporary nature of relationships and low profits to contractors emerge from furious rivalry in this industry, made contractors become opportunist to recover at least the cost (Meng et al., 2011). Contractors' opportunistic behaviour is defined as the contractor's acts of exercising private control, conceal or alter information, disengage from commitments or promises, avoid obligations, and breaches explicit or implicit agreements, trying to earn for themselves at the expense of the owner (Luo, 2006). 


\subsection{MINIMISING THE CONTRACTORS' OPPORTUNISTIC BEHAVIOUR}

Strong form $\mathrm{OB}$ is progressively recognisable by owners, which diminishes the inclination of contractors to violate contracts (Luo, 2006). Furthermore, Luo (2006) mentioned that strong form OB is culpable dependent on terms and statements or clauses of contracts, while there were no principles to follow to remedy losses caused by weak form $\mathrm{OB}$. At the point when clients take measures to punish contractors for weak form OB without enough evidence, it might prompt clashes and in any event, bring an end to transactions, causing more prominent misfortunes (Shi et al., 2018). Moreover, if clients to manage the behaviour appropriately, they should recognise behaviour, collect evidence, estimate losses, negotiate, and bargain with contractors and implement solutions, which will bring about significant transaction costs (Luo, 2006). Contrasting transaction costs with actual losses, clients would, in general, persevere through their accomplices' weak form $\mathrm{OB}$ and learn a lesson, except there are incredibly extreme results (Luo et al., 2015).

In the construction sector, one of the essential explanations for project failures is the unequal division of risks between client and contractor (Rahman and Kumaraswamy, 2002). Laan et al. (2011) identified that different parties, including public bodies, were using new contract forms that focused on improving project performance by balancing and preventing the risks between client and contractor through new types of formal and informal control. Academics and practitioners attempt to discover powerful techniques to forestall COB in the last decades (Lu et al., 2015). Most common methods were project management (ul Musawir et al., 2020), project alliance (Laan et al., 2011), and project governance (Too and Weaver, 2014). Project management is used to meet the project requirements by utilising knowledge, skills, tools, and techniques to carry out project activities (PMI, 2013). Project alliances were introduced to evade the unsupportive patterns of conduct looked by client and contractor organisations in traditional and design-build types of contract (Laan et al., 2011).

\subsection{BENEFITS AND DRAWBACKS OF MINIMISING CONTRACTORS' OPPORTUNISTIC BEHAVIOUR}

Opportunism has negative impacts on the relationship between the client and contractors and the general procedure of a construction project (Lu et al., 2016). Furthermore, authors mentioned that due to the major impacts of opportunism, researchers have concentrated on the most proficient method to limit it. Mitropoulos and Howell (2001) said that the contract used as the main measure to govern COB.

A complete contract can decrease the vulnerability of decision making and it prompts to limit the intentions of OB (Williamson, 1985). An outside party can make a judgment in relation to the contract agreement thus it limits the extent of OB (Anderson and Dekker, 2005). Besides, more obligations increase contractors' knowledge to their obligations and duties, accordingly it grows the obligation to the relationship. Because of a paranoid fear for harsh punishment, the contractors would pay attention to the terms of the agreement seriously and would not embrace an opportunistic method to staying away from their duties (Lu et al., 2016). Contracts can determine unsatisfactory behaviour thus, the code of behaviour seems transparent and it is completely clear what behaviour ought to be monitored in order to see whether the other party disregards the agreement, in this manner diminishing monitoring expenses (Reuer and Ariño, 2002). Parties might become flexible 
and alludes to the eagerness to adjust and change the original terms of the contract encountering specific requests of the other party (Yilmaz et al., 2005). Detailed terms in the contract also show that client has doubts about the contractors (Cavusgil et al., 2004).

\subsection{What is Project Governance?}

Project governance system possesses a focal situation for guaranteeing that projects understand their business case and the target benefits expressed in that, which thusly bolsters the usage of the organisational strategy (Hjelmbrekke et al., 2014). PG operates at the top level and includes the creation and usage of an arrangement of checks intended to settle project decision-making aligns with the targets of providing funds to the entity (Biesenthal and Wilden, 2014). Locatelli et al. (2014) identified PG as a budding field, that has as of late become an area of interest in the executive community related to the field of project management (Samset and Volden, 2016).

Müller et al. (2015) investigated how the PG structure is impacted by corporate governance (CG). Furthermore, the authors identified institutional enablers impact the determination and execution of PG and found that the presence of PG mechanisms. On the other hand, Müller et al. (2016) investigated the relationship between PG and CG and its impact on moral issues in temporary organisations such as project-based organisations by utilising institutional theory and agency theory. Authors considered that CG instruments substitute PG instruments, formal control, and social control to decrease moral issues. Table 1 shows definitions provided by authors on project governance.

Table 1: Definitions of project governance

\begin{tabular}{ll}
\hline \multicolumn{1}{c}{ Author } & \multicolumn{1}{c}{ Definition } \\
\hline Turner $(2009$, p. 311) & $\begin{array}{l}\text { The governance of a project involves a set of relationships between the } \\
\text { project's management, its sponsor (or executive board), its owner and } \\
\text { other stakeholders. It provides the structure through which the objectives } \\
\text { of the project are set, and the means of attaining those objectives and } \\
\text { monitoring performance are determined. }\end{array}$ \\
PMI (2013, p. 579) & $\begin{array}{l}\text { The alignment of project objectives with the strategy of the larger } \\
\text { organisation by the project sponsor and project team. A project's } \\
\text { governance is defined by and is required to fit within the larger context } \\
\text { of the program or organisation sponsoring it but is separate from } \\
\text { organisational governance. } \\
\text { Governance, as it applies to portfolios, programs, projects, and project } \\
\text { management, coexists within the corporate governance framework. It } \\
\text { comprises the value system, responsibilities, processes, and policies that } \\
\text { allow projects to achieve organisational objectives and foster } \\
\text { implementation that is in the best interests of all the stakeholders, } \\
\text { internal and external, and the corporation itself. }\end{array}$ \\
\hline
\end{tabular}

It was identified that $\mathrm{COB}$ has a negative impact on project performance. Minimising COB would provide benefits such as parties become more transparent as well as flexible. Hence, PG can be used to minimise the effects of $\mathrm{COB}$ on project performance. The literature review reveals that there were few or no sources accessible about the utilisation of PG to limit COB in Sri Lankan construction industry. Therefore, essential to look at the effect on using PG to minimise COB in Sri Lankan construction industry. 


\section{RESEARCH METHODOLOGY}

Research approach is the procedure for research, which traverses the choices from more extensive assumptions to more informative methods of data collection and analysis (Creswell, 2014). Yin (2017) presented two types of research approaches as Qualitative and Quantitative. The qualitative approach is subjective in nature. Creswell (2014) mentioned that qualitative approach incorporate gathering data and information through raising questions and strategies comprehensive of researcher making interpretations of the data. Considering the merits and demerits of the research approaches, qualitative approach was selected over the quantitative and mixed approaches. Yin (2011) clarified the points of interest as could concentrate on explicit arrangement of individuals, in depth study on wider areas, offer more prominent scope in choosing topics and representing the perspectives and viewpoints of the individuals. In depth opinion of the industry practitioners under case studies were needed to propose suitable PG modes to the local context. On the other hand, PG was a new development thus the projects that use this concept was extremely limited in the Sri Lankan construction industry. Hence, the obtainable sample size was limited. Furthermore, the data and information gathered were mostly based on the opinion of the practitioners and needed to be analysed in detail. Therefore, the study needed to be done based on the qualitative approach.

The background study was carried out by referring to books, journal articles, electronic sources, and other relevant sources and then the research gap was identified to carry forward the research. A comprehensive literature survey was conducted to review opportunistic behaviour, $\mathrm{COB}, \mathrm{PG}$ and client's choice on PG modes to minimise contractors' opportunistic behaviour. Journal articles, books, conference proceedings and unpublished dissertations helped with building up the literature review. Considering the fact that the literature relating to project governance was hard to find and ultimate objective of the research is to evaluate the suitability of the project governance modes to minimise the contractors' opportunistic behaviour in Sri Lankan construction industry, case study analysis was selected. Four building construction projects were selected as cases. Out of four, two projects had a public client, and the other two projects had a private client. The study is based on a qualitative approach and therefore qualitative data was collected through the semi structured interviews. Analysis procedure of those qualitative data was incorporated recognising, coding, and categorising patterns. Further, a content analysis was utilised as the data analysis technique.

\section{RESEARCH FINDINGS AND ANALYSIS}

Four building construction projects were selected as cases. Cases A and B were governed by formal control mode, case $\mathrm{C}$ was governed mostly based on trust and case $\mathrm{D}$ was governed by a combination of two modes. The public institute held ownership for two projects and the other two project had private owners. Out of four cases, only case $\mathrm{C}$ did not have a consultant for their selected project. Cases related to both modes were selected in order to get an idea about the applicability of each mode to the Sri Lankan context and to investigate whether using different project governance modes are feasible and beneficial to use in Sri Lankan construction industry. Other than that, choosing public and private projects lead to provide different perspective regarding the project governance mode used in the respective cases. The interviews were carried out among sixteen professionals who are currently involved in the Sri Lankan construction industry in four 
different cases. A brief description of the four cases has been shown in Table 2 and Table 3 provides a brief description about respondents.

Table 2: Details of selected cases

\begin{tabular}{lclll}
\hline & Case A & \multicolumn{1}{c}{ Case B } & \multicolumn{1}{c}{ Case C } & \multicolumn{1}{c}{ Case D } \\
\hline $\begin{array}{l}\text { Nature of the } \\
\text { project }\end{array}$ & $\begin{array}{l}\text { Building } \\
\text { construction }\end{array}$ & $\begin{array}{l}\text { Building } \\
\text { construction } \\
\text { and renovation }\end{array}$ & $\begin{array}{l}\text { Building } \\
\text { construction }\end{array}$ & $\begin{array}{l}\text { Building construction } \\
\text { including hotels and } \\
\text { apartments }\end{array}$ \\
$\begin{array}{l}\text { Project duration } \\
\text { Tendering } \\
\text { method }\end{array}$ & $\begin{array}{c}\text { 6 months } \\
\text { Open tendering }\end{array}$ & 2 Years & $\begin{array}{l}\text { 2 Years } \\
\text { Direct negotiation }\end{array}$ \\
$\begin{array}{l}\text { Standard form } \\
\text { of contract } \\
\text { Governance } \\
\text { mode used }\end{array}$ & Standard Bidding Document (SBD 2) & FIDIC \\
\hline & Formal Control & $\begin{array}{l}\text { Both but } \\
\text { mostly } \\
\text { Trust }\end{array}$ & $\begin{array}{l}\text { Combination of both Trust } \\
\text { and Formal Control } \\
\text { equally }\end{array}$ \\
\hline
\end{tabular}

Table 3: Details of respondents

\begin{tabular}{|c|c|c|c|c|c|}
\hline Case & $\begin{array}{l}\text { Respondent } \\
\text { Code }\end{array}$ & $\begin{array}{l}\text { Type of the } \\
\text { organisation }\end{array}$ & $\begin{array}{c}\text { Ownership } \\
\text { of the } \\
\text { organisation }\end{array}$ & Designation & $\begin{array}{l}\text { Experience } \\
\text { in the } \\
\text { industry }\end{array}$ \\
\hline \multirow[t]{4}{*}{$\begin{array}{c}\text { Case } \\
\text { A }\end{array}$} & RA1 & Client & Public & $\begin{array}{l}\text { Chief Manager Technical } \\
\text { Services }\end{array}$ & 30 years \\
\hline & RA2 & Consultant & Private & Chief Architect & 12 Years \\
\hline & RA3 & Contractor & Private & Project Manager & 10 Years \\
\hline & RA4 & Contractor & Private & $\begin{array}{l}\text { Project Quantity } \\
\text { Surveyor }\end{array}$ & 8 Years \\
\hline \multirow[t]{4}{*}{$\begin{array}{c}\text { Case } \\
\text { B }\end{array}$} & RB1 & Client & Public & $\begin{array}{l}\text { Assistant Director } \\
\text { Construction }\end{array}$ & 5 Years \\
\hline & RB2 & Consultant & Public & Chief Engineer & 24 Years \\
\hline & RB3 & Contractor & Private & Chief Quantity Surveyor & 9 Years \\
\hline & $\mathrm{RB} 4$ & Contractor & Private & Chief Quantity Surveyor & 35 Years \\
\hline \multirow[t]{4}{*}{$\begin{array}{c}\text { Case } \\
\text { C }\end{array}$} & $\mathrm{RC} 1$ & Client & Private & $\begin{array}{l}\text { Director Project } \\
\text { Management }\end{array}$ & 20 Years \\
\hline & $\mathrm{RC} 2$ & Client & Private & Senior Quantity Surveyor & 8 Years \\
\hline & $\mathrm{RC} 3$ & Contractor & Private & $\begin{array}{l}\text { Project Quantity } \\
\text { Surveyor }\end{array}$ & 3 Years \\
\hline & $\mathrm{RC} 4$ & Contractor & Private & Project Manager & 11 Years \\
\hline \multirow{4}{*}{$\begin{array}{c}\text { Case } \\
\text { D }\end{array}$} & RD1 & Client & Private & Director (CFO) & 3 Years \\
\hline & $\mathrm{RD} 2$ & Consultant & Private & Director Operation & 25 Years \\
\hline & RD3 & Contractor & Private & Project Manager & 10 years \\
\hline & RD4 & Contractor & Private & Director Projects & 14 Years \\
\hline
\end{tabular}


The researcher asked about the respondents opinion on the; (a) meaning of PG, (b) importance of project governance to construction projects, (c) impact of contractors' opportunistic behaviour to the construction industry, (d) benefits of minimising opportunistic behaviour, (e) factors affect to the contractors' opportunistic behaviour, (f) relationship between contractors' opportunistic behaviour and the client's choice on project governance modes, and (g) suitable project governance mode to construction projects in Sri Lanka. The answers given by 16 respondents in the 4 cases are given below.

\subsection{Meaning of Project Governance}

Professionals identified what the project governance was meant for the construction industry of Sri Lanka. They provided different views regarding it. These are the few definitions provided by them. One respondent identified it as a method that helps in timely procurement. Six respondents identified PG as a method that can be used to manage and control a construction project in order to get the expected outcome. One respondent had a view that it was a process of decision making in a construction project in order to make the project effective, efficient, and transparent. From the views of respondents, it can be said that project governance is a process that can be used to manage and control a construction project in order to get an expected outcome from it within expected time and cost.

\subsection{Importance of Project Governance to Construction PROJECTS}

Different respondents added different ideas on why they thought PG is an important attribute to practice. A respondent had a view "Good project governance shall streamline the project decision making process so the confusions and lack of trust in decision making are minimised as much as possible". Following are the reasons to consider PG as an important attribute as identified by the professionals.

- Guide to go in one direction

- Can get the expected outcome

- Minimise conflicts

- Improve project decision making

- Leads to timely completion and time saving

- Better management of resources

- Provide quality output

- Can complete within budget

Through the literature review it was identified that PG must be, built up to empower productive and viable project decision-making and it was identified by RA4 and RC3.

\subsection{IMPACT OF CONTRACTORS' OPPORTUNISTIC BEHAVIOUR TO THE CONSTRUCTION INDUSTRY}

Professionals were questioned about the impact of $\mathrm{COB}$ to the construction industry and professionals provided valuable insight into the impact with their experience. Their ideas are summarised as follows:

- Could lead to time and cost overruns

- Quality may be affected 
- Project objectives would not be achieved

- Dissatisfaction could occur between parties

- Contractors will be blacklisted.

- Claims will be increased in the industry.

- Demotivate the clients in investing

- Affect to all other stakeholders

- Leads to mistrust between all parties

\subsection{BENEFITS OF MINIMISING OPPORTUNISTIC BEHAVIOUR}

The benefits of minimising opportunistic behaviour identified through the literature synthesis and responses collected from interviews were also summarised in Table 3.

Table 3: Benefits of minimising opportunistic behaviour

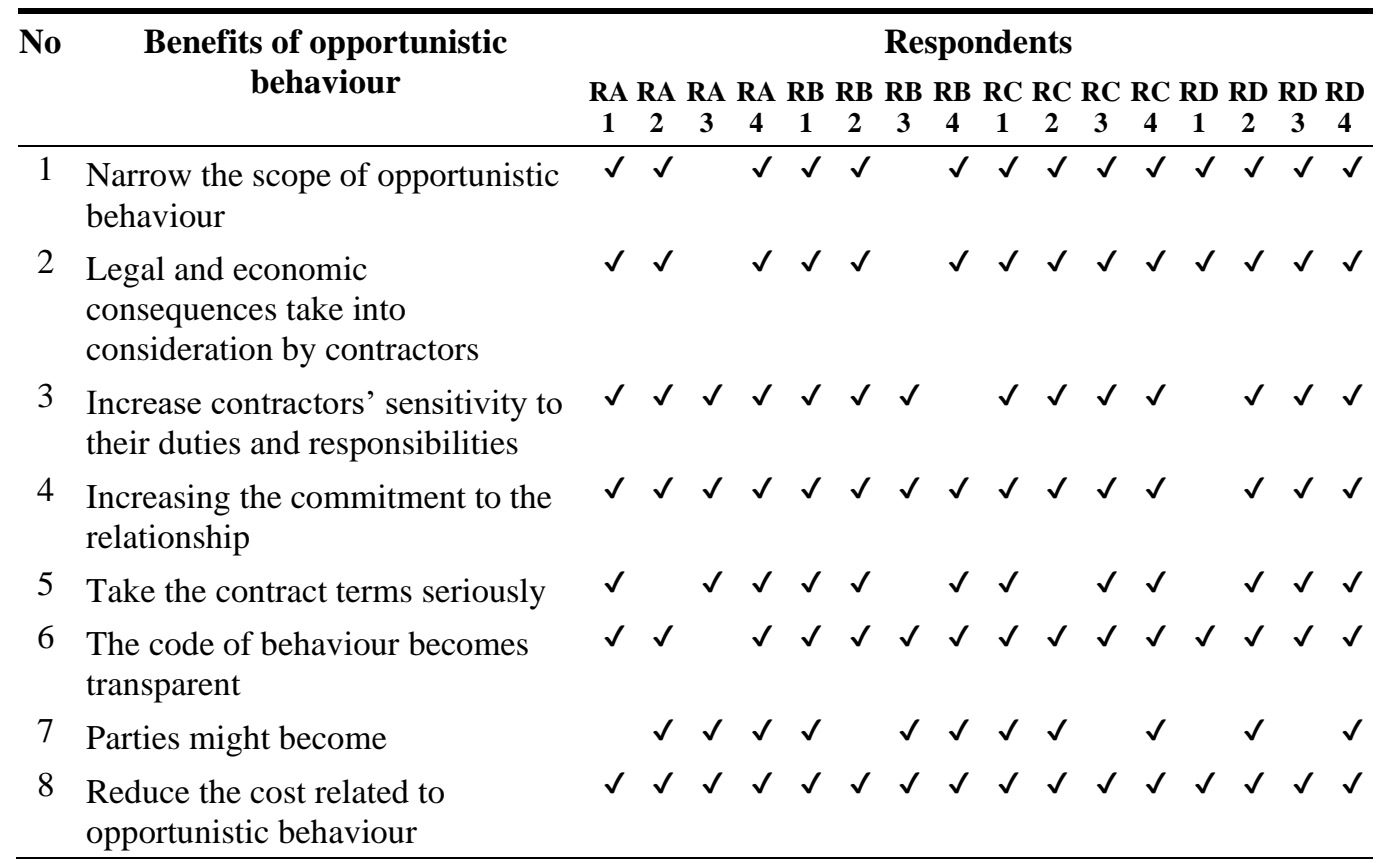

RB4 said that "Contractors are always sensitive to their duties if there is a proper management within the contractor's organisation and when they are ethical. Thus, the minimising it will not have a huge impact". RA2 highlighted that contractors would always take contract terms seriously when they get into a contract thus it led them to identify the areas that they can get benefits from.

\subsection{FACTORS AFFECTING TO CONTRACTORS' OPPORTUNISTIC BEHAVIOUR}

The factors affecting contractors' opportunistic behaviour identified through the literature synthesis, which was validated through the interviews are listed below:

- Client's prevention focus and promotion focus

- Contractor's focus on revenue maximisation, short time to completion, taking projects as security and relationship marketing

- Internal and external uncertainty

- Control, coordination and adaptation related to contractual complexity 
- Structural complexity, uncertainty, dynamic complexity, pace and socio-political under project complexity

All respondents agreed to all factors related to the contractual complexity and all respondents agreed to the factors namely contractor's focus on revenue maximisation, external uncertainty, structural complexity, uncertainty under project complexity, dynamic complexity, and pace under project complexity. According to that, it was clear when contract become complex contractors tend to be opportunistic because of the freedom they did not get from it. Other than that, when contractor is focusing on revenue maximisation, they will be opportunistic, because it was the only way they can generate more profit from a project. Furthermore, when the project is technically difficult, uncertainties are highly related to the project, frequent changes instructed by the Employer and milestones needed to achieve in the project will also affect to the COB.

\subsection{RELATIONSHIP BETWEEN CONTRACTORS' OPPORTUNISTIC BEHAVIOUR AND THE Client's CHOICE ON Project Governance ModeS}

It was identified that there is a relationship between contractors' opportunistic behaviour and the client's choice on project governance modes because all the respondents mentioned that $\mathrm{COB}$ would have an impact when the client selects a project governance mode. Too and Weaver (2014) mentioned that PG can be used as a method to minimise the opportunistic behaviour of the parties in a construction project. RB1, RB2, RC3 and $\mathrm{RD} 1$ mentioned that based on the client's experience on previous projects related to the $\mathrm{COB}$, clients would choose a project governance mode. If the methods used previously not helped to control the COB and it led to losses for client most probably client would select a different governance mode. Furthermore, all respondents mentioned that there are some factors affect client's choice on PG other than COB. Few of them are time, cost, quality, nature of the project, complexity of the project and focus of the client.

\subsection{Suitable Project Governance Mode to Construction PROJECTS IN SRI LANKA}

It was identified that at the beginning, construction industry must go for either formal control mode or a hybrid mode of formal control and the trust. Apart from a one respondent, no one mentioned trust could be used as a PG mode in Sri Lankan construction industry and respondent one respondent mentioned that the selection of the mode would depend on the factors that needed to analyse when selecting a PG mode. RA1 mentioned "If a combination of trust and formal control can be used in Sri Lanka it will be better but as per the current scenario, formal control is the best because contractors are not ethical." RB1 mentioned that contract must be there to make sure all parties contribute to a project but when there is trust it can lead to make decisions suit for all parties.

The study revealed that it is hard to totally eliminate $\mathrm{COB}$ in the construction industry and it meant that project governance cannot eliminate contractor's opportunistic behaviour by $100 \%$ but it would help to achieve minimisation of it to the greater extent. Both formal control mode and the combination of trust and formal control mode have identified by the professional as suitable modes for the construction industry. 


\section{CONCLUSIONS}

The changing nature of the construction industry, its competitiveness and work environment that affected by internal and external factors have forced the firms to find out relevant management strategies to achieve objectives of the projects for the client. Project governance is a framework, which was adopted for construction projects in the global context over the past few years. In order to cope up with the change in the industry, it needed to be adopted in the Sri Lankan context.

According to the background literature review, there are lack of studies related to the use of PG to minimise COB in the Sri Lankan construction industry. It was further revealed that construction industry practitioners paid less attention to the clients' choice regarding PG modes and their ability to control the COB. Hence, there was a need to investigate the use of PG to reduce the effect of COB to maximise the project performance and identify the factors that directly affect to the COB. This study revealed that formal control and combination of trust and formal control as the most suitable PG modes for Sri Lankan construction industry. Therefore, this research offers factors to consider when selecting a PG mode such as complexity, duration, and cost of the project. Furthermore, the research identified the factors that affect the COB namely, contractors focus on revenue maximisation, external uncertainties, contractual complexity, and dynamic complexity. The study further revealed the importance of minimising COB such as helps to minimise conflicts and reduces the financial losses incurred for project stakeholders.

Research findings confirmed that PG is existing in the construction industry as a management method, and it can be used to overcome the COB. This study exposed that, even though PG is used worldwide, it was a new field to Sri Lanka, yet it was used in construction projects without knowing with project management. Hence, this research offers insights about PG in order to enhance project performance by minimising the COB.

Findings of this research will be beneficial for the construction industry practitioners, for increase the project performance in Sri Lankan construction organisations by minimising $\mathrm{COB}$ in order to enlighten the corporate image of the industry and increase the satisfaction of all stakeholders in a project as recommended below.

1. Employing the findings of this research as guidance to select a suitable PG mode out of formal control and combination of trust and formal control.

2. Use the findings of this research to promote the use of PG in Sri Lankan construction industry

\section{REFERENCES}

Anderson, S.W. and Dekker, H.C., 2005. Management control for market transactions: The relation between transaction characteristics, incomplete contract design, and subsequent performance. Management Science, 51(12), pp. 1734-1752.

Bankvall, L., Bygballe, L.E., Dubois, A. and Jahre, M., 2010. Interdependence in supply chains and projects in construction. Supply Chain Management: An international journal, 15(5), pp. 385-393.

Biesenthal, C. and Wilden, R., 2014. Multi-level project governance: Trends and opportunities. International Journal of Project Management. 32(8), pp. 1291-1308.

Cavusgil, S.T., Deligonul, S. and Zhang, C., 2004. Curbing foreign distributor opportunism: An examination of trust, contracts, and the legal environment in international channel relationships. Journal of International Marketing, 12(2), pp. 7-27. 
Cheung, S.O., Yiu, T.W., Leung, A.Y.T. and Chiu, O.K., 2014. Catastrophic transitions of construction contracting behaviour. Journal of Construction Engineering and Management, 134(12), pp. 942-952.

Creswell, J.W., 2014. Research design: Qualitative, quantitative, and mixed methods approaches. $4^{\text {th }} \mathrm{ed}$. United States of America: SAGE Publications, Inc.

Crosno, J.L. and Dahlstrom, R., 2008. A meta-analytic review of opportunism in exchange relationships. Journal of the Academy of Marketing Science, 36(2), pp. 191-201.

Das, T.K. and Rahman, N., 2010. Determinants of partner opportunism in strategic alliances: A conceptual Framework. Journal of Business and Psychology, 25(1), pp. 55-74.

Drexler Jr, J.A. and Larson, E.W., 2000. Partnering: Why project owner-contractor relationships change. Engineering, 126(4), pp. 293-297.

Hjelmbrekke, H., Lædre, O. and Lohne, J., 2014. The need for a project governance body. International Journal of Managing Projects in Business, 7(4), pp. 661-677.

Laan, A., Voordijk, H. and Dewulf, G., 2011. Reducing opportunistic behaviour through a project alliance. International Journal of Managing Projects in Business, 4(4), pp. 660-679.

Locatelli, G., Mancini, M. and Romano, E., 2014. Systems Engineering to improve the governance in complex project environments. International Journal of Project Management. 32(8), pp. 1395-1410.

Love, P.E.D., Irani, Z. and Edwards, D.J., 2004. A seamless supply chain management model for construction. Supply Chain Management, 9(1), pp. 43-56.

Lu, P., Guo, S., Qian, L., He, P. and Xu, X., 2015. The effectiveness of contractual and relational governances in construction projects in China. International Journal of Project Management. Elsevier B.V., 33(1), pp. 212-222.

Lu, P., Qian, L., Chu, Z. and Xu, X., 2016. Role of opportunism and trust in construction projects: Empirical evidence from China. Journal of Management in Engineering, 32(2), pp. 1-10.

Lu, W., Zhang, L. and Zhang, L., 2016. Effect of contract completeness on contractors' opportunistic behaviour and the moderating role of interdependence. Journal of Construction Engineering and Management, 142(6), pp. 1-10.

Luo, Y., 2006. Opportunism in inter-firm exchanges. Management of Organization Review, 2(1), pp. 121147.

Luo, Y., Liu, Y., Yang, Q., Maksimov, V. and Hou, J., 2015. Improving performance and reducing cost in buyer-supplier relationships: The role of justice in curtailing opportunism. Journal of Business Research, 68(3), pp. 607-615.

Meng, X., 2015. The role of trust in relationship development and performance improvement. Journal of Civil Engineering and Management, 21(7), pp. 845-853.

Meng, X., Sun, M. and Jones, M., 2011. Maturity model for supply chain relationships in construction. Journal of Management in Engineering, 27(2), pp. 97-105.

Mitropoulos, P. and Howell, G., 2001. Model for understanding, preventing, and resolving project disputes, Journal of Construction Engineering and Management, 127(3), pp. 223-231.

Müller, R., 2009. Project governance surrey: Gower Publishing Company.

Müller, R., Zhai, L., Wang, A. and Shao, J., 2016. A framework for governance of projects: Governmentality, governance structure and projectification. International Journal of Project Management, 34(6), pp. 957-969.

Müller, R., Pemsel, S. and Shao, J., 2015. Organizational enablers for project governance and governmentality in project-based organizations. International Journal of Project Management, 33(4), pp. 839-851.

Paswan, A.K., Hirunyawipada, T. and Iyer, P., 2017. Opportunism, governance structure and relational norms: An interactive perspective. Journal of Business Research, 77, pp. 131-139. 
PMI., 2013. A guide to the project management body of knowledge, Project Management Institute. [Online] Available from: https://book.akij.net/eBooks/2018/March/5abcc35b666f7/a\%20guide\%20to\%20the\%20project\%20ma nagement $\% 20$ body\%20of\%20knowledge\%206e.pdf

Rahman, M.M. and Kumaraswamy, M.M., 2002. Joint risk management through transactionally efficient relational contracting, Construction Management and Economics, 20(1), pp. 45-54.

Reuer, J.J. and Ariño, A., 2002. Contractual renegotiations in strategic alliances. Journal of Management, 28(1), pp. 47-68.

Samset, K. and Volden, G.H., 2016. Front-end definition of projects: Ten paradoxes and some reflections regarding project management and project governance, International Journal of Project Management., 34(2), pp. 297-313.

Shi, C., Chen, Y., You, J. and Yao, H., 2018. Asset specificity and contractors' opportunistic behaviour: Moderating roles of contract and trust, Journal of Management in Engineering, 34(5), pp. 1-12.

Sulong, Z., Fazeuraida TMR S.N., Arifin, M.R., and Hartini Ab.G., 2018. Earnings quality at the IPOs: The Influence of opportunistic behaviour and ownership control mechanisms, International Journal of Academic Research in Business and Social Sciences, 8(12), pp. 1265-1277.

Too, E.G. and Weaver, P., 2014. The management of project management: A conceptual framework for project governance, International Journal of Project Management. 32(8), pp. 1382-1394.

Turner, J.R., 2008. The handbook of project-based management: Leading strategic change in organizations, p. 452. [Online] Available from: http://www.amazon.com/The-Handbook-Project-based-ManagementOrganizations/dp/0071549749.

ul Musawir, A., Abd-Karim, S.B. and Mohd-Danuri, M.S., 2020. Project governance and its role in enabling organizational strategy implementation: A systematic literature review, International Journal of Project Management. 38(1), pp. 1-16.

Verbeke, A., Ciravegna, L., Lopez, L.E., and Kundu, S.K., 2019. Five configurations of opportunism in international market entry. Journal of Management Studies, 56(7), pp. 1287-1313.

Williamson, O.E., 1985. The economic institutions of capitalism: Firms, markets, relational contracting, University of Illinois at Urbana-Champaign's Academy for Entrepreneurial Leadership Historical Research Reference in Entrepreneurship, [Online] Available from: SSRN: https://ssrn.com/abstract=1496720

Yilmaz, C., Sezen, B. and Ozdemir, O., 2005. Joint and interactive effects of trust and (inter) dependence on relational behaviours in long-term channel dyads. Industrial Marketing Management, 34(3), pp. 235248.

Yin, R.K., 2017. Case study research and applications: Design and methods. SAGE Publications.

Yin, R.K., 2011. Qualitative Research from start to finish. $2^{\text {nd }} \mathrm{ed}$. The Guilford Press.

Zhang, L. and Qian, Q., 2017. How mediated power affects opportunism in owner-contractor relationships: The role of risk perceptions. International Journal of Project Management., 35(3), pp. 516-529. 